\title{
Characterization of Embryos Derived From Calf Oocytes: Kinetics of Cleavage, Cell Allocation to Inner Cell Mass, and Trophectoderm and Lipid Metabolism
}

\author{
V. MAJERUS, ${ }^{1}$ A.S. LEQUARRÉ, ${ }^{1}$ E.M. FERGUSON,${ }^{2}$ S. KAIDI, ${ }^{1}$ A. MASSIP, ${ }^{1}$ F. DESSY, ${ }^{1}$ AND I. DONNAY ${ }^{1 *}$ \\ ${ }^{1}$ Université Catholique de Louvain, Unité des Sciences Vétérinaires, Croix du Sud 3, Louvain-la-Neuve, Belgium \\ ${ }^{2}$ Department of Biology, University of York, GB-York, United Kingdom
}

\begin{abstract}
Embryos derived from calf oocytes were compared with adult cow oocyte-derived embryos (1) by studying the kinetics of embryo development using time-lapse cinematography (2) by evaluating the ratio between inner cell mass (ICM) and trophectoderm (TE) cells in blastocysts ( 3 ) by measuring the triglyceride content of the blastocysts. The rate of calf oocyte-derived embryos reaching the blastocyst stage was reduced (26 vs. $46 \%$ for adult derived embryos). Calf oocyte-derived embryos preferably arrested their development before the 9-cell stage. Those that developed into blastocysts had cleaved earlier to reach the 2-cell or 3-cell stages than embryos that arrested before the 9-cell stage. The 9-cell stage tended to appear later in calf oocyte-derived embryo that reached the blastocyst stage than in adult-derived embryos. This difference became significant at the morula stage. Accordingly, the fourth cell cycle duration was longer for calf oocyte-derived embryos. Day 8 blastocysts from both sources had similar total cell numbers (calf: $89 \pm 20$; cow: $100 \pm 30$ ) and cell distribution between TE and ICM. The triglyceride content of day 7 blastocysts was similar for both sources ( $64 \pm 15$ vs. $65 \pm 6 \mathrm{ng} / \mathrm{embryo}$, respectively). In conclusion, calf oocyte-derived embryos are characterized by a higher rate of developmental arrest before the 9-cell stage and by a longer lag phase preceding the major onset of embryonic genome expression. These changes might be related to insufficient "capacitation" of the calf oocyte during follicular growth. Despite these differences, modifications in the quality of the resulting blastocysts were not detected. Mol. Reprod. Dev. 57:346-352, 2000. (c) 2000 Wiley-Liss, Inc.
\end{abstract}

Key Words: kinetics; in vitro embryo production; calf oocyte; lipid; differential staining

\section{INTRODUCTION}

The use of prepubertal heifers as oocyte donors in breeding programs could increase the annual genetic gain by decreasing the generation interval (Lohuis, 1995). Moreover, calf ovaries exhibit larger pools of antral follicles visible on their surface than adult ovaries (Erickson, 1966), thus offering the potential of recovering more oocytes at the same time.

In vitro maturation (IVM), in vitro fertilization (IVF) and embryo culture (IVC) were applied to oocytes collected from calf ovaries by follicle aspiration (Armstrong et al., 1992; Revel et al., 1995; Khatir et al., 1996; Presicce et al., 1997; Majerus et al., 1999). Embryos were obtained but their developmental rates and viability after transfer were on average lower than for embryos derived from adult oocytes (Revel et al., 1995; Damiani et al., 1996; Khatir et al., 1996; Presicce et al., 1997; Tervit et al., 1997; Fry et al., 1998). However, Armstrong et al. (1992) and Earl et al. (1998) obtained a high rate of blastocyst formation $(28 \%$; $46 \%)$ from oocytes collected on FSH-stimulated calves. We also obtained reasonable developmental rates (19-27\%) from oocytes collected by transvaginal oocyte retrieval from unstimulated 8 month old calves (Majerus et al., 1999). Pregnancy rates after transfer varied between studies: from 5 to 50\% (Armstrong et al., 1994; Revel et al., 1995; Earl et al., 1998; Fry et al., 1998). In all studies, the fetal losses during the first trimester of pregnancy were particularly high (30-100\%, Amstrong et al., 1994; Revel et al., 1995; Fry et al., 1998) suggesting that the quality of blastocysts obtained from calf oocytes may be poor.

Although several studies have characterized calf oocytes before, during and after IVM (Levesque and Sirard, 1994; Damiani et al., 1996; Khatir et al., 1996; Gandolfi et al., 1998), few data are available on the characteristics of the embryos derived from them. The aims of the present study were to compare various aspects of the quality of calf oocyte-derived embryos with those of cow oocyte-derived embryos. Three

Grant sponsor: Ministère des Classes Moyennes et de l'Agriculture de Belgique; Grant numbers: 5737A and S5867; Grant sponsor: Ministère de la Region Wallonne de Belgique; Grant sponsor: Direction Générale de la Recherche Scientifique-Communauté française de Belgique; Grant number: 96/01-196.

*Correspondance to: Isabelle Donnay, Université Catholique de Louvain, Unité des Sciences Vétérinaires, Place Croix du Sud 3, B-1348 Louvain-la-Neuve, Belgium. E-mail: donnay@vete.ucl.ac.be Received 7 February 2000; Accepted 4 May 2000 
parameters were evaluated: (i) the kinetics of cleavage by time-lapse cinematography, (ii) cell allocation to the inner cell mass (ICM) and the trophectoderm (TE) and (iii) the triglyceride content of the blastocysts.

The timing of the first cleavage division has been reported to be indicative of developmental potential in early bovine embryos (Plante and King, 1992; Van Soom et al., 1992; Grisart et al., 1994; Holm et al., 1998): the faster the embryos cleave, the more chance they have of developing into blastocysts. The blastocyst consists of two distinct cell populations: the trophectoderm (TE) and the inner cell mass (ICM). The ICM will differentiate into all tissues of the developing fetus. The $\mathrm{TE}$ is responsible for maternal recognition of pregnancy and is involved in the formation of placenta and extraembryonic membranes (Stojkovic et al., 1998). These two different cell types can be distinguished by using a differential staining technique which has been applied to embryos from different species, including the bovine (Iwasaki et al., 1990; Van Soom et al., 1996; Kaidi et al., 1998; Khatir et al., 1998; Stojkovic et al., 1998). It has been suggested that the number of blastomeres at a given age and their allocation to ICM and TE are related to embryo viability (Papaioannou and Ebert, 1988). Cattle embryos contain considerable amounts of lipid in the form of triglyceride, the amount of which is influenced by culture conditions (Ferguson and Leese, 1999). Moreover, IVP bovine blastocysts accumulated more lipids than their in vivo counterparts, which could be related to their higher sensitivity to cryopreservation (Pollard and Leibo, 1993).

The aims of this work were (1) to study the timing of calf embryo development by time-lapse cinematography (2) to characterize blastocysts derived from the fertilization of calf oocytes by comparison with embryos derived from cow oocytes cultured in the same conditions in terms of total cell numbers, ratio between ICM and TE cells and (3) triglyceride content.

\section{MATERIALS AND METHODS Embryo Production}

Ovaries from 6 to 8 month old calves and adult cows were collected at a local slaughterhouse and processed in parallel. Cumulus oocyte complexes (COCs) were aspirated from 2 to $7 \mathrm{~mm}$ diameter follicles and matured in Tissue Culture Medium 199 with Earle's salts, L-glutamine and $\mathrm{NaHCO}_{3}$ (Sigma, St Louis, MO) containing $10 \%$ heat-inactivated Fetal Calf Serum (ICN Biochemicals) and $10 \mathrm{ng} \mathrm{ml}{ }^{-1}$ Epidermal Growth Factor (Sigma). Maturation was performed in a humidified atmosphere of $5 \% \mathrm{CO}_{2}$ in air at $39^{\circ} \mathrm{C}$ for 22-26 hr.

Matured COCs were fertilized in TALP-low bicarbonate $\left(2 \mathrm{mg} \mathrm{ml}^{-1}\right)$ Tyrode's medium containing $6 \mathrm{mg} / \mathrm{ml}$ fatty acid-free albumin fraction $\mathrm{V}$ (Sigma), $4 \mathrm{mg} \mathrm{ml}^{-1}$ sodium lactate (Sigma), $0.11 \mathrm{mg} \mathrm{ml}^{-1}$ sodium pyruvate (Sigma) with 1.7 IU ml ${ }^{-1}$ heparin-sodium salt (Sigma). Motile spermatozoa were obtained by centrifugation of frozen-thawed spermatozoa on a Percoll discontinuous density gradient (Pharmacia, Uppsala, Sweden). The same batch of semen was used throughout the experiments. Semen was diluted to obtain a final concentration of $2 \times 10^{6}$ spermatozoa $\mathrm{ml}^{-1}$ and coincubated with COCs for $18 \mathrm{hr}$ in a humidified atmosphere of $5 \% \mathrm{CO}_{2}$ in air at $39^{\circ} \mathrm{C}$.

Presumptive zygotes were denuded by vortexing and cultured under paraffin oil in 20- $\mu$ l droplets of Synthetic Oviduct Fluid (SOF) modified according to Holm et al. (1997) containing $2.8 \mathrm{mM}$ myo-inositol, $0.3 \mathrm{mM}$ citrate and 5\% FCS. Culture was performed in a humidified atmosphere of $5 \% \mathrm{CO}_{2}, 5 \% \mathrm{O}_{2}$ and $90 \% \mathrm{~N}_{2}$ at $39^{\circ} \mathrm{C}$.

\section{Experiment 1: Time-Lapse Cinematographic Study}

To perform the time-lapse cinematographic study, embryos were placed in a cinematographic chamber on the plate of an inverted microscope (Zeiss). The chamber was flushed for $15 \mathrm{~min}$ every $30 \mathrm{~min}$ with a humidified, warmed gas mixture consisting of $5 \% \mathrm{CO}_{2}$, $5 \% \mathrm{O}_{2}, 90 \% \mathrm{~N}_{2}$. To maintain a constant temperature of $39^{\circ} \mathrm{C}$ a plexiglas box was adapted to fit onto the microscope and connected to a heating system controlled by a temperature probe. The recording equipment consisted of a color video camera KY-F55E (JVC, Japan) and two computers. The first computer synchronized the lighting of the lamp and the shooting. The second recorded the frames with the program Perception Video Recorder (Alpha M, Belgium). One image was recorded every $90 \mathrm{sec}$.

Development of embryos was filmed under $160 \times$ magnification for 8 days from the zygote stage $(18 \mathrm{hpi})$. Movies were analyzed by measuring, for each embryo, the time of appearance of 2-cell, 3-cell, 5-cell, 9-cell, morula, blastocyst and hatched blastocyst stages. Only the embryos visible in the camera field throughout the culture period were examined. Four and three movies were recorded for calf and cow oocytes-derived embryos, respectively.

\section{Experiment 2: Differential Staining}

Embryos were produced as previously described in an incubator. On day 8 post insemination hatched and unhatched blastocysts derived from calf and cow oocytes were differentially stained.

The zona pellucida of unhatched blastocysts was removed by treatment with pronase $(0.5 \%$ Protease, Sigma) for $1-2 \mathrm{~min}$ at $37^{\circ} \mathrm{C}$ followed by treatment for 1 min with acidic Tyrode (pH 2.1) (Nicolson et al., 1975). Zona pellucida-free embryos were allowed to recover for $4-5 \mathrm{hr}$ in culture medium containing 5\% FCS. Differential cell counts of inner cell mass and trophectoderm were carried out according to the method of Hardy et al. (1989) as modified by Van Soom et al. (1996). Briefly, trinitrobenzene-sulfonic acid (TNBS; Sigma) and rabbit anti-dinitrophenol-BSA (ICN Biochemicals) were used for labeling trophectoderm cells; guinea pig complement (ICN Biochemicals) was then added to lyse the trophectoderm cells and nuclei 
stained with propidium iodide (PI; Sigma) and bisbenzimide (Hoechst 33342; Calbiochem). ICM nuclei labeled with bisbenzimide appeared blue and those of trophectoderm labeled with both bisbenzimide and propidium iodide appeared pink when examined by fluorescence microscopy.

\section{Experiment 3: Triglyceride Content}

Embryos were produced as previously described in an incubator. Day 7 blastocysts derived from calf and cow oocytes were collected in groups of three and frozen in $5 \mu \mathrm{l}$ microcaps in $\mathrm{Ca}^{2+}, \mathrm{Mg}^{2+}$ free PBS containing BSA $(1 \mathrm{mg} / \mathrm{ml})$ and FCS (30\%), according to the method of Ferguson and Leese (1999). Samples were stored at $-80^{\circ} \mathrm{C}$ until use. The triglyceride content was measured according to the method of Ferguson and Leese (1999). Briefly the assay is based on the hydrolysis of triglycerides to glycerol and free fatty acids followed by enzymatic measurement of the glycerol released. The glycerol is transformed in lactate by a series of reactions in which $\mathrm{NADH}$ is oxidized to $\mathrm{NAD}^{+}$. The amount of $\mathrm{NADH}$ oxidized is proportional to the amount of glycerol in the sample and may be quantified using a fluorescent microscope with photometer and photomultiplier attachments.

\section{Statistical Analysis}

One-way analysis of variance ANOVA 1 was used to compare the mean times of cleavage and duration of cell cycles for calf and cow embryos. A Chi-square analysis was used to compare embryos from calf and cow oocytes that were arrested between the 2-cell and 9-cell stages.

Results for differential staining were subjected to a 3way ANOVA (oocyte source, blastocyst stage and replicate). Data were transformed by $2 x(\arcsin [s-$ quare-root]) before analysis, to normalize their distribution (Dagnelie, 1986). A one-way ANOVA (oocyte source) was used to compare the triglyceride content between calf and cow oocyte-derived blastocysts.

\section{RESULTS}

\section{Developmental Kinetics of Embryos Derived From Calf and Cow Oocytes}

The mean rate of 5-8 cell stage (on oocytes) at day 3 post insemination was $49 \%$ (40/81) for embryos derived from calf oocytes and 67\% (35/52) for embryos derived from cow oocytes (Chi-square, $P>0.05$ ). Blastocyst rates (on oocytes) at day 8 post insemination were respectively of $26 \%$ (calf) and $46 \%$ (cow) (Chi-square, $P<0.05)$.

Of the 74\% (60/81) embryos derived from calf oocytes that were arrested before the blastocyst stage, $67 \%$ (40/60) did so between the 2-cell and 9-cell stages. For cow embryos however only $18 \%(5 / 28)$ of the embryos that did not reach the blastocyst stage ceased development during those two cell cycles (Chi-square, $P<0.01)$.

Calf embryos that developed into blastocysts by day 8 had cleaved earlier at the 2-cell, 3-cell stage than those that did not develop beyond the 8-cell stage (Table 1, $P<0.05)$. Due to the low number of embryos that became arrested before the 8-cell stage, the analysis was not performed for cow oocyte-derived embryos.

As the main objective of our study was to compare the quality of blastocysts derived from calf and cow oocytes, only data on embryos reaching the blastocyst stage will be included in the following calculations (calf: $n=21$; cow: $n=24$ ). Although no difference was detectable between calf and cow oocyte-derived embryos in the mean time of appearance of the 2, 3 and 5-cell stages, the 9-cell stage tended to appear later in calf embryos (Table 2 and Fig. 1, $P=0.07$ ). This difference became significant at the morula stage $(P=0.013)$ where a difference of roughly $9 \mathrm{hr}$ was observed between the two sources of embryos. Such a difference was not apparent at the blastocyst stage. Accordingly, the fourth cell cycle duration was longer for calf than for cow oocytederived embryos (Table $3, P=0.04$ ).

TABLE 1. Comparison of the Time (Hours and Minutes) at Which Calf Oocyte-Derived Embryos Reached the 2-Cell, 3-Cell or 5-Cell Stages, According to the Developmental Stage They Had Reached at Day 8 (Blastocyst, $\leq$ 8-Cell-Stage)

\begin{tabular}{|c|c|c|}
\hline & \multicolumn{2}{|c|}{ Stage reached at day 8} \\
\hline & Blastocyst & $\leq 8$-cell \\
\hline 2-cell stage & $\begin{array}{c}25 \mathrm{hr} 41 \pm 1 \mathrm{hr} 58^{\mathrm{a}} \\
(\mathrm{n}=21)\end{array}$ & $\begin{array}{c}29 \mathrm{hr} 04 \pm 6 \mathrm{hr} 09^{\mathrm{b}} \\
(\mathrm{n}=40)\end{array}$ \\
\hline 3-cell stage & $\begin{array}{c}31 \mathrm{hr} 25 \pm 4 \mathrm{hr} 12^{\mathrm{a}} \\
(\mathrm{n}=21)\end{array}$ & $36 \mathrm{hr} 14 \pm 9 \mathrm{hr} 02^{\mathrm{b}}$ \\
\hline 5 -cell stage & $\begin{array}{c}42 \mathrm{hr} 15 \pm 9 \mathrm{hr} 16^{\mathrm{a}} \\
(\mathrm{n}=21)\end{array}$ & $\begin{array}{c}45 \mathrm{hr} 31 \pm 9 \mathrm{hr} 43^{\mathrm{b}} \\
(\mathrm{n}=13)\end{array}$ \\
\hline
\end{tabular}

Values are means \pm SD of time post insemination.

a,b Values within the same row with different superscripts are significantly different (ANOVA1). 
TABLE 2. Mean Time of Appearance (In Hours and Minutes) of 2-Cell, 3-Cell, 5-Cell, 9-Cell, Morula, and Blastocyst Stage for Calf and Cow Oocyte-Derived Embryos that Subsequently Reached the Blastocyst Stage on Day 8 Post Insemination

\begin{tabular}{lcc}
\hline & \multicolumn{2}{c}{ Mean time $\pm \mathrm{SD}$} \\
\cline { 2 - 3 } Stages & $\begin{array}{c}\text { Calf } \\
(\mathrm{n}=21)\end{array}$ & $\begin{array}{c}\text { Cow } \\
(\mathrm{n}=24)\end{array}$ \\
\hline 2-cell & $25 \mathrm{hr} 41 \pm 1 \mathrm{hr} 59^{\mathrm{a}}$ & $25 \mathrm{hr} 36 \pm 1 \mathrm{hr} 53^{\mathrm{a}}$ \\
3-cell & $31 \mathrm{hr} 25 \pm 4 \mathrm{hr} 12^{\mathrm{a}}$ & $32 \mathrm{hr} 50 \pm 3 \mathrm{hr} 09^{\mathrm{a}}$ \\
5-cell & $42 \mathrm{hr} 15 \pm 9 \mathrm{hr} 16^{\mathrm{a}}$ & $43 \mathrm{hr} 36 \pm 4 \mathrm{hr} 20^{\mathrm{a}}$ \\
9-cell & $87 \mathrm{hr} 48 \pm 15 \mathrm{hr} 50^{\mathrm{a}}$ & $80 \mathrm{hr} 21 \pm 10 \mathrm{hr} 22^{\mathrm{a}}$ \\
Morula & $103 \mathrm{hr} 18 \pm 15 \mathrm{hr} 01^{\mathrm{a}}$ & $94 \mathrm{hr} 12 \pm 7 \mathrm{hr} 54^{\mathrm{b}}$ \\
Blastocyst & $143 \mathrm{hr} 27 \pm 7 \mathrm{hr} 48^{\mathrm{a}}$ & $139 \mathrm{hr} 10 \pm 13 \mathrm{hr} 02^{\mathrm{a}}$ \\
\hline
\end{tabular}

Values are means $\pm \mathrm{SD}$ of time post insemination.

a,b Values within the same row with different superscripts are significantly different (ANOVA1).
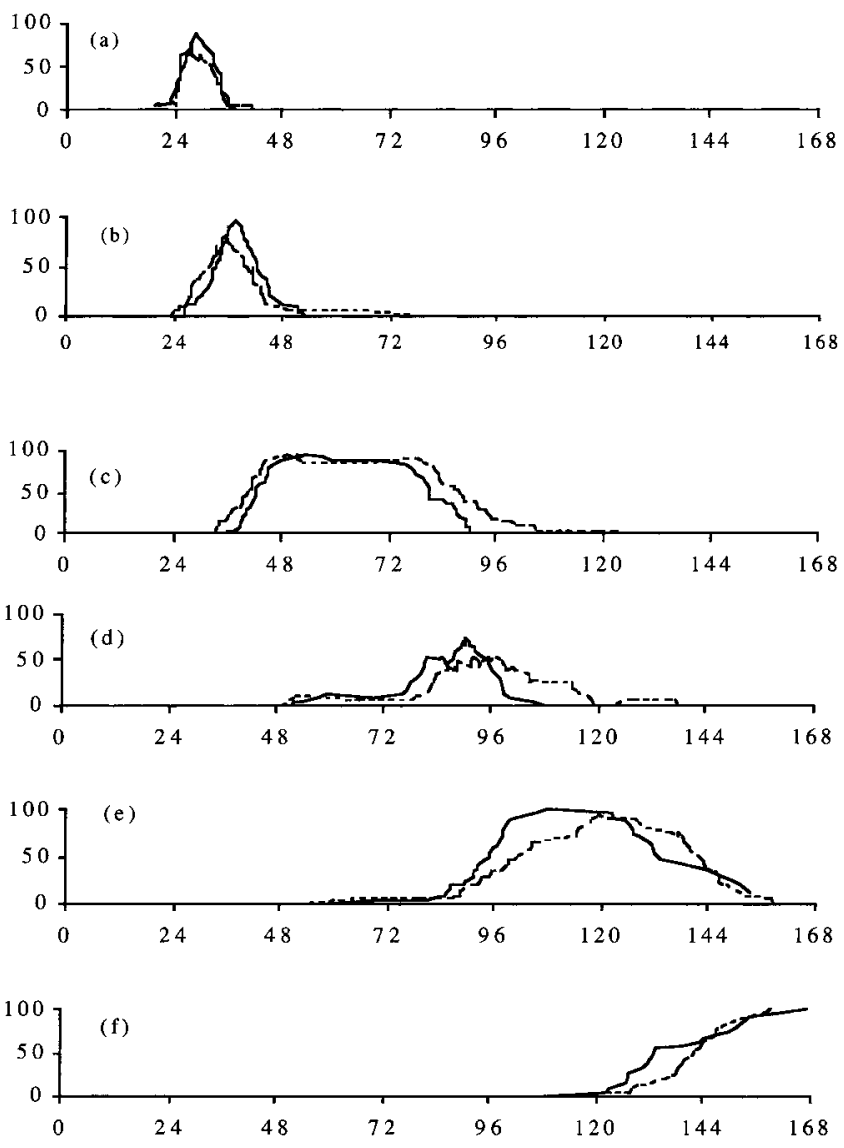

Fig. 1. Development of calf (- - -) and cow (-) embryos that became blastocysts by the end of the culture period. Proportion (\%) with time (expressed in hours post insemination) of (a) 2-cell embryos, (b) 3-cell embryos, (c) 5-cell embryos, (d) 9-cell embryos, (e) morulae and (f) blastocysts.

\section{Differential Staining For Calf and Cow Blastocysts}

Day 8 blastocysts from both sources had similar total cell numbers (calf: $89 \pm 20$; cow: $100 \pm 30$ ). No difference (three-way ANOVA, $P<0.05$ ) was observed in cell distribution between TE and ICM for hatched and unhatched blastocysts derived from calf or cow oocytes (Table 4).

\section{Triglyceride Content}

No difference was observed in the triglyceride content of calf and cow day 7 blastocysts ( $64 \pm 15$ vs. $65 \pm 6 \mathrm{ng} /$ embryo respectively, mean $\pm \mathrm{SD}$ ).

\section{DISCUSSION}

A variety of studies have indicated that oocytes from calf ovaries are less developmentally competent than those from cow ovaries (Revel et al., 1995; Khatir et al., 1996; Khatir et al., 1998). This was confirmed in the present study: the percentage of blastocysts obtained from calf oocytes was reduced in comparison with those from adults animals (26\% vs. $46 \%$, cinematographic chamber).

While the kinetics of cleavage of bovine embryos has been widely studied (Grisart et al., 1994; Van Langendonckt et al., 1997; Van Soom et al., 1997; Holm et al., 1998) this is, to our knowledge, the first report on the kinetics of development of calf oocyte-derived embryos. Sixty seven percent (40/60) of calf embryos that did not reach the blastocyst stage ceased development before the 9-cell stage vs. $18 \%$ (5/28) for cow embryos. The first cell divisions of the bovine embryo are regulated by maternal mRNA and proteins accumulated in the oocyte prior to the resumption of meiosis; the main onset of embryonic genome (maternal/zygotic transition) occurs in the cow at the 9-16 cell stage (Barnes and Eyestone, 1990; Telford et al., 1990). It is thus likely that calf embryos that became arrested before the 9-cell stage showed defects in the acquisition of oocyte developmental competence. The acquisition of developmental competence is a continuous process beginning with oocyte growth (up to the early antral follicle) and continuing with the phase of "capacitation" which occurs in the adult cow in follicles from $2-3 \mathrm{~mm}$ of diameter up to the preovulatory follicle stage $(15 \mathrm{~mm}$, Hyttel et al., 1997). The oocyte growth period is under local control while the capacitation period is under the control of both local and systemic factors. Hormonal 
TABLE 3. Cell Cycle Lengths (In Hours and Minutes) of Calf and Cow OocyteDerived Embryos that Reached the Blastocyst Stage on Day 8

\begin{tabular}{|c|c|c|}
\hline \multirow[b]{2}{*}{ Cell cycle } & \multicolumn{2}{|c|}{ Mean time \pm SD } \\
\hline & $\begin{array}{c}\text { Calf } \\
(\mathrm{n}=21)\end{array}$ & $\begin{array}{c}\text { Cow } \\
(\mathrm{n}=24)\end{array}$ \\
\hline First (1 to 2 -cell) & $25 \mathrm{hr} 41 \pm 1 \mathrm{hr} 59^{\mathrm{a}}$ & $25 \mathrm{hr} 36 \pm 1 \mathrm{hr} 53^{\mathrm{a}}$ \\
\hline Second (2 to 3 -cell) & $5 \mathrm{hr} 45 \pm 3 \mathrm{hr} 28^{\mathrm{a}}$ & $7 \mathrm{hr} 15 \pm 3 \mathrm{hr} 06^{\mathrm{a}}$ \\
\hline Third (3 to 5-cell) & $10 \mathrm{hr} 49 \pm 7 \mathrm{hr} 09^{\mathrm{a}}$ & $10 \mathrm{hr} 46 \pm 5 \mathrm{hr} 06^{\mathrm{a}}$ \\
\hline Fourth (5 to 9 -cell) & $45 \mathrm{hr} 34 \pm 16 \mathrm{hr} 09^{\mathrm{a}}$ & $36 \mathrm{hr} 45 \pm 11 \mathrm{hr} 06^{\mathrm{b}}$ \\
\hline Five (9-cell to morula) & $15 \mathrm{hr} 29 \pm 9 \mathrm{hr} 26^{\mathrm{a}}$ & $13 \mathrm{hr} 51 \pm 9 \mathrm{hr} 18^{\mathrm{a}}$ \\
\hline Six (morula to blastocyst) & $40 \mathrm{hr} 09 \pm 16 \mathrm{hr} 50^{\mathrm{a}}$ & $44 \mathrm{hr} 58 \pm 14 \mathrm{hr} 10^{\mathrm{a}}$ \\
\hline
\end{tabular}

Values are means \pm SD.

${ }_{\mathrm{a}, \mathrm{b}}$ Values within the same row with different superscripts are significantly different (ANOVA1).

TABLE 4. Cell Number and Allocation to Inner Cell Mass (ICM) and Trophectoderm (TE) of Day 8 Blastocysts Originating From Calf or Cow Oocytes

\begin{tabular}{llccccc}
\hline & & \multicolumn{3}{c}{${\text { Cell number }(\text { mean } \pm \mathrm{SD})^{\mathrm{a}}}$} \\
\cline { 4 - 5 } Oocyte source & Blastocyst stage & $\mathrm{n}$ & $\mathrm{TE}$ & $\mathrm{ICM}$ & Total & ICM/Total \\
\hline Calf & Unhatched & 24 & $63 \pm 22$ & $24 \pm 5$ & $87 \pm 24$ & $0.29 \pm 0.07$ \\
& Hatched & 20 & $67 \pm 14$ & $25 \pm 9$ & $92 \pm 14$ & $0.27 \pm 0.09$ \\
& Total & & $65 \pm 19$ & $24 \pm 7$ & $89 \pm 20$ & $0.28 \pm 0.08$ \\
Cow & & & & & \\
& Unhatched & 28 & $64 \pm 19$ & $26 \pm 9$ & $90 \pm 25$ & $0.28 \pm 0.06$ \\
& Hatched & 28 & $83 \pm 27$ & $27 \pm 11$ & $111 \pm 32$ & $0.25 \pm 0.08$ \\
& Total & & $74 \pm 25$ & $26 \pm 10$ & $100 \pm 30$ & $0.27 \pm 0.07$ \\
\hline
\end{tabular}

${ }^{a}$ No significant difference was found between calf and cow embryos (ANOVA3, $P>0.05$ ).

profiles are known to be different in prepubertal animals (Melvin et al., 1999). The hypothesis of a defect in capacitation in oocytes collected from calf ovaries is sustained by the study of Gandolfi et al. (1998) and Steeves and Gardner (1999) comparing the sizes of the oocytes collected from follicles of $2-5 \mathrm{~mm}$ in calf and cow ovaries. Indeed, calf oocytes had on average a lower diameter $(112-118 \mu \mathrm{m})$ than cow oocytes $(117-123 \mu \mathrm{m})$ and several studies demonstrated that the diameter of the oocyte correlates directly with its capacity to reach the metaphase II stage (Fair et al., 1995) and to sustain embryo development (Otoi et al., 1997).

In relation to the maternal/zygotic transition, a developmental arrest (lag phase) has been observed between the 5-8-cell stage and the 9-16 cell stage in in-vitro grown bovine embryos (Grisart et al., 1994). For calf oocyte-derived embryos, this arrest was also present, with the 4 th cell cycle being much longer than the other cell cycles. Moreover, this cell cycle was significantly longer for calf oocyte-derived embryos by comparison with cow embryos, even for embryos reaching the blastocyst stage. This could be due to a delay in the onset of transcription of the zygotic genome related to a defect in the oocyte capacitation process (Telford et al., 1990). Consequently, the 9-cell and morula stage appearances were delayed for calf oocytederived embryos.
Previous studies on bovine embryos suggest that the first embryos to reach a given early cleavage stage (2 and 3-cell) have a better chance of developing into blastocysts (Plante and King, 1992; Van Soom et al., 1992; Grisart et al., 1994; Holm et al., 1998). This was confirmed for calf oocyte-derived embryos in this study.

Calf oocyte-derived embryos could be divided into two categories on the basis of their kinetics of development: those that were arrested during early cleavage stages, and those that reached the blastocyst stage but with a delay in the maternal-zygotic transition. In the other experiments of this study we tried to discover if this delay in comparison to cow oocyte-derived embryos affected the quality of the blastocysts as measured by the number of cells, cell allocation to ICM and TE and triglyceride content.

Several studies reported that the ability of calf embryos to establish and maintain a pregnancy is limited (Revel et al., 1995; Fry et al., 1998; Brogliatti et al., 1999). This could be due to an abnormal cell number of the ICM and TE. However, no differences were observed in total cell number or in cell distribution (TE and ICM) in hatched and unhatched blastocysts derived from calf and cow oocytes. Similar results were obtained by Khatir et al. (1998).

Although several studies have examined the metabolism of calf oocytes (Levesque and Sirard, 1994; Khatir et al., 1996; Gandolfi et al., 1998; Steeves and 
Gardner, 1999), few data are available on the metabolism of calf oocyte-derived embryos. No significant differences were noted in the constitutive and the neosynthetic protein profiles between cow and calf embryos obtained in vitro (Khatir et al., 1998). Moreover, no perturbation in nutrient uptakes (glucose, pyruvate) was observed for calf oocyte-derived embryos that reached the blastocyst stage (Steeves et al., 1999). We present here data on lipid metabolism in calf blastocysts. Triglycerides are the main class of lipid synthesized in mouse embryos (Flynn and Hillman, 1978). Their major biological function in adult tissues is to serve as energy store. Pollard and Leibo (1993) showed in a densitometry study that in vitro produced embryos derived from cow oocytes had a lower density than those derived in vivo. This was related to a higher lipid/protein ratio of in vitro embryos probably resulting from an unbalanced lipid metabolism. This unbalance was negatively correlated to the chilling sensitivity of the blastocysts and their resistance to cryopreservation (Pollard and Leibo, 1993; Nagashima et al., 1994) and may be involved in the large calf syndrome (Sata et al., 1999). From our results, calf oocyte-derived blastocysts grown in the same culture conditions showed the same accumulation of triglyceride at the blastocyst stage as cow oocyte-derived embryos ( $64 \pm 15 \mathrm{ng}$ vs. $65 \pm 6 \mathrm{ng}$ per embryo), suggesting that their lipid metabolism is similar. The present values are somewhat higher than those obtained by Ferguson and Leese (1999) for bovine blastocysts of the same age (day 7) though grown in slightly different conditions.

In conclusion, the present study reports differences in the kinetics of development of embryos derived from calf as opposed to cow oocytes: calf oocyte-derived embryos are characterized by a higher rate of developmental arrest before the 9-cell stage and by a longer duration of the lag phase preceding the major onset of embryonic genome expression. These changes might be related to anomalies in the capacitation process of the calf oocyte due to the immaturity of the regulation of follicular growth before puberty. Despite these differences, the quality of the resulting blastocysts, measured by the total number of cells, the ratio between ICM and TE cells and the triglyceride contents, was similar for the two classes of embryo. Further investigations are needed to understand the origin of the low viability of calf oocyte-derived embryos.

\section{ACKNOWLEDGMENTS}

We thank Dr P. Mermillod (INRA, Tours, France) for his suggestions and fruitful discussion of the results. We thank V. Labrique, S. Bernard, A. Van Heule and P. Bombaerts for technical assistance and thank Prof. $\mathrm{H}$. Leese (University of York, UK) for critically reading the manuscript. This research was supported by grants 5737A and S5867 from "Ministère des Classes moyennes et de l'Agriculture de Belgique," by "Ministère de la Région wallonne de Belgique" and by "Action de Recherche Concertée, No. 96/01-196" de la Direction générale de la Recherche Scientifique —Communauté française de Belgique.

\section{REFERENCES}

Armstrong DT, Holm P, Irvine B, Petersen BA, Stubbings RB, McLean D, Stevens G, Seamark RF. 1992. Pregnancies and live birth from in vitro fertilisation of calf oocytes collected by laparoscopic follicular aspiration. Theriogenology 38:667-678.

Armstrong DT, Irvine B, Earl CR, McLean D, Stevens G, Seamark RF. 1994. Gonadotropin stimulation regimens for follicular aspiration and in vitro embryo production from calves oocytes. Theriogenology 42:1227-1236.

Barnes FL, Eyestone WH. 1990. Early cleavage and maternal zygotic transition in bovine embryos. Theriogenology 33:141-152.

Brogliatti GM, Furnus CC, De Matos DG, Martinez AG. 1999. In vitro fertilisation program in prepuberal brangus calves and later embryo collection. Theriogenology 51:313.

Dagnelie P. 1986. Les méthodes de l'inférence statistique In Gembloux Agronomics Press, editor. Théorie et méthodes statistiques. Gembloux, Belgium p 213-240.

Damiani P, Fissore RA, Cibelli JB, Long CR, Balise JJ, Robl JM, Duby RT. 1996. Evaluation of developmental competence, nuclear and ooplasmic maturation of calf oocytes. Mol Reprod Dev 45: 521-534.

Earl C, Fry RC, Maclellan LJ, Kelly J, Armstrong DT. 1998. In vitro fertilisation and development potential of prepubertal calf oocytes. In: Lauria A, Gandolfi F, Enne G, Gianaroli L, editors. Serono Symposia, Gametes: Development and Function. Rome. p 115-137.

Erickson BH. 1966. Development and senescence of the postnatal bovine ovary. J Anim Sci 25:800-805.

Fair T, Hyttel P, Greve T. 1995. Bovine oocyte diameter in relation to maturational competence and transcriptional activity. Mol Reprod Dev 42:437-442

Ferguson E, Leese H. 1999. Triglyceride content of bovine oocytes and early embryos J Reprod Fertil 116:373-378.

Flynn TJ, Hillman N. 1978. Lipid synthesis from [U-14C]-glucose in preimplantation mouse embryos in culture. Biol Reprod 19: 922-926.

Fry RC, Simpson TL, Squires TJ. 1998. Ultrasonically guided transvaginal oocyte recovery from calves treated with or without GnRH. Theriogenology 49:1077-1082.

Gandolfi F, Milanesi E, Pocar P, Luciano AM, Brevini TAL, Acocella F, Lauria A, Armstrong DT. 1998. Comparative analysis of calf and cow oocytes during in vitro maturation. Mol Reprod Dev 49: $168-175$.

Grisart B, Massip A, Dessy F. 1994. Cinematographic analysis of bovine embryo development in serum-free oviduct-conditioned medium J Reprod Fertil 101:257-264.

Hardy K, Handyside A, Winston R. 1989. The human blastocyst: cell number, death and allocation during late preimplantation development in vitro. Development 107:597-604.

Holm P, Booth P, Vajta G, Callesen H. 1997. A protein-free SOF system supplemented with amino acids, sodium citrate and myoinositol. Proceedings of the 13th Association Européenne de Transfert Embryonnaire, Lyon, p 158.

Holm P, Shukri NN, Vajta G, Booth P, Bendixen C, Callesen H. 1998 Developmental kinetics of the first cell cycles of bovine in vitro produced embryos in relation to their in vitro viability and sex. Theriogenology 50:1285-1299.

Hyttel P, Fair T, Callesen H, Greve T. 1997. Oocyte growth, capacitation and final maturation in cattle. Theriogenology 47: $23-32$.

Iwasaki S, Yoshiba N, Ushijima H, Watanabe S, Nakahara T. 1990 Morphology and proportion of inner cell mass of bovine blastocysts fertilized in vitro and in vivo. J Reprod Fertil 90:279-284.

Kaidi S, Donnay I, Van Langendonckt A, Dessy F, Massip A. 1998 Comparison of two-coculture systems to assess the survival of in vitro produced bovine blastocysts after vitrification. Anim Reprod Sci 52:39-50.

Khatir H, Lonergan P, Carolan C, Mermillod P. 1996. Prepubertal bovine oocyte: a negative model for studying oocyte developmental competence. Mol Reprod Dev 45:2131-2319. 
Khatir H, Lonergan P, Touzé JL, Mermillod P. 1998. The characterization of bovine embryos obtained from prepubertal calf oocytes and their viability after non surgical embryo transfer. Theriogenology 50:1201-1210.

Levesque JT and Sirard MA. 1994. Proteins in oocytes from calves and adult cows before maturation: relationships with their developmental capacity. Reprod Nutr Dev 34:133-139.

Lohuis MM. 1995. Potential benefits of bovine embryo-manipulation technologies to genetic improvement programs. Theriogenology 43:51-60.

Majerus V, De Roover R, Etienne D, Kaidi S, Massip A, Dessy F, Donnay I. 1999. Embryo production by ovum pick up in unstimulated calves before and after puberty. Theriogenology, 52: $1169-1179$.

Melvin EJ, Lindsey BR, Quintal-Franco J, Zanella E, Fike KE, Van Tassel CP, Kinder JE. 1999. Circulating concentrations of Estradiol, Luteinizing Hormone, and Follicle-Stimulating Hormone during waves of avarian follicular development in prepubertal cattle. Biol Reprod 60:405-412.

Nagashima H, Kashiwasaki N, Ashman RJ, Grupen CG, Seamark RF, Nottle MB. 1994. Removal of cytoplasmic lipid enhances the tolerance of porcine embryos to chilling Biol Reprod 51:618-622.

Nicolson G, Yanagimachi R, Yanagimachi H. 1975. Ultrastructural localization of lectin-binding sites on the zona pellucida and plasmamembranes of mammalian eggs. J Cell Biol 66:263-274.

Otoi T, Yamamoto K, Koyama N, Tachikawa S, Suzuki T. 1997. Bovine oocyte diameter in relation to developmental competence. Theriogenology 48:769-774.

Papaioannou V, Ebert K. 1988. The preimplantation pig embryo: cell number and allocation to trophectoderm and inner cell mass of the blastocyst in vivo and in vitro. Development 102:793-803.

Plante L, King WA. 1992. Effect of time to first cleavage on hatching rate of bovine embryo in vitro. Theriogenology 37:274.

Pollard JW, Leibo SP. 1993. Comparative cryobiology of in vitro and in vivo derived bovine embryos. Theriogenology 39:287.

Presicce GA, Jiang S, Simkin M, Zhang L, Looney CR, Godke RA, Yang X. 1997. Age and hormonal dependence of acquisition of oocyte competence for embryogenesis in prepubertal calves. Biol Reprod $56: 386-392$.
Revel F, Mermillod P, Peynot N, Renard JP, Heyman Y. 1995. Low developmental capacity of in vitro matured and fertilized oocytes from calves compared with that of cows. J Reprod Fertil 103:115-120.

Sata R, Tsijii H, Abe H, Yamashita S, Hoshi H. 1999. Fatty acid composition of bovine embryos cultured in serum-free and serumcontaining medium during early embryonic development. J Reprod Dev 45:97-103.

Steeves TE, Gardner DK. 1999. Metabolism of glucose, pyruvate, and glutamine during the maturation of oocytes derived from prepubertal and adult cows. Mol Reprod Dev 54:92-101.

Steeves TE, Gardner DK, Zuelke KA, Squires TS, Fry RC. 1999 In vitro development and nutrient uptake by embryos derived from oocytes of pre-pubertal and adult cows. Mol Reprod Dev 54: $49-56$.

Stojkovic M, Büttner M, Zakhartchenko V, Brem G, Wolf E. 1998. A reliable procedure for differential staining of in vitro produced bovine blastocysts: comparison of tissue culture medium 199 and Ménézo's 2 medium. Anim Reprod Sci 50:1-9.

Telford N, Watson A, Schultz G. 1990. Transition from maternal to embryonic control in early mammalian development: a comparison of several species. Mol Reprod Dev 26:90-100.

Tervit H, McMillan W, McGowan L, Smith J, Hall D, Donnison M. 1997. Effect of juvenile calf age on follicular dynamics and in vitro embryo production. Theriogenology 47:300.

Van Langendonckt A, Donnay I, Schuurbiers N, Auquier P, Carolan C, Massip A, Dessy F. 1997. Effects of supplementation with fetal calf serum on development of bovine embryos in synthetic oviduct fluid medium. J Reprod Fertil 109:87-93.

Van Soom A, De Kruif A. 1992. A comparative study of in vivo and in vitro derived bovine embryos Proceedings of the 12th International Congress of Animal Reproduction, The Hague, 3:1363-1365.

Van Soom A, Boerjan M, Ysebaert M-T, De Kruif A. 1996. Cell allocation to the inner cell mass and the trophectoderm in bovine embryos cultured in two different media. Mol Reprod Dev 45: 171-182.

Van Soom A, Ysebaert M-T, De Kruif A. 1997. Relationship between timing of development, morula morphology, and cell allocation to inner cell mass and trophectoderm in in vitro-produced bovine embryos. Mol Reprod Dev 47:47-56. 